elementary at solar temperatures. It will be seen that the issue raised then could not be complained of as lacking crispness and definiteness. What then are the facts? The facts have been exactly as they were predicted on the rival hypothesis - the hypothesis, namely, that the elements are not elementary; and in future we are not likely to hear much more of the "reversing layer." The solar spectrum, indeed, appears now to be the result of the absorptive work of an innumerable number of strata one over the other, from top to bottom of the solar atmosphere. If we could see the work of any one of these layers by itself, it would be impossible for us, with our mere terrestrial laboratory experience, to recognise it, whereas we do recognise the sum total, because we get, and can only get as a rule, a sum total in our laboratory experiments. Should this result be generally accepted as one of the results of this year's work a great step will have been gained. Whether accepted or not, it is quite clear that such observations as those to which attention has been directed will demand much attention when next the sun is eclipsed. Nor is this all. It is not too much to hope now that $M$. Thollon has so admirably succeeded in furnishing astronomers with a spectroscope which combines the maximum of dispersion and light that observations suggested by the new view may be made on the uneclipsed sun and bring their tribute of precious facts every day the sun shines. Such work, indeed, was actually started at Sohag, and the test then afforded gave out no uncertain sound; but on this point it is not necessary to enlarge upon the present occasion, as both MM. Thollon and Trépied are pledged to utilise the beautiful climates of Nice and Algiers in carrying on this new survey at the earliest possible moment, and the world of science will doubtless soon hear something of the result of this new attack.

There is little doubt that on the occasion of future eclipses attention will be much more concentrated on the spectrum of the corona, and more specially-constructed instruments will be brought to bear on it than has been the case hitherto. We may already take for granted that the blue lines photographically recorded (in addition to $\mathrm{H}$ and $\mathrm{K}$ in the violet, ) will have their position determined with the greatest accuracy, and their coincidence or not with marked Fraunhofer lines will have an important bearing upon the questions to which attention has been directed in the present letter. The work, too, has shown that the new plates are so sensitive that it will be quite easy at the next eclipse by means of a circular rotating plate, or some such contrivance, to record all the spectroscopic phenomena, however evanescent they may be, visible at the moment of disappearance or reappearance of the sun. Such a method will not only give us a complete history of what goes on, but will furnish us with a scale of exact reference. So science advances. Each effort, and especially the one most wisely planned, instead of exhausting the supply of new phenomena brings still newer efforts and richer harvests in its train.

I have been very unfaithful to the task imposed upon me if I have not convinced your readers that the expeditions whose work it was my duty to chronicle have been richly rewarded for their long preparations and tedious journeyings. They will all leave Egypt with the liveliest sense of gratitude for the manner in which all their efforts for the advancement of knowledge among men have been seconded by the Khedive and the Egyptian Government.

\section{PROF. W. B. ROGERS}

THE death is announced of Prof. William Barton Rogers, whose name is so well known in connection with the Massachusetts Institute of Technology at Boston, U.S. Prof. Rogers died suddenly' of apoplexy, while giving an address, on May 30 last, in connection with the Annual Graduating Exercises of the Institute. From the Boston Daily Advertiser we obtain some facts concerning Prof. Rogers' life and work:-

William Barton Rogers, the second son of four in a family noted for its scientific acquirements, was born in Philadelphia, in December, I805. His father, Patrick Kerr Rogers, was a learned and enthusiastic lover of natural science, and is credited with being among the first in the United States to establish systematic courses of instruction in chemistry and experimental physics for the general public. Young Rogers was educated at William and Mary College, in which institution his father had been appointed Professor of Natural Philosophy and Chemistry. At the age of twenty-one he delivered, at the Maryland Institute, Baltimore, his first lectures on science, and one year later he succeeded to his father's position as professor at William and Mary College. In I 835 he accepted the appointment to the chair of natural philosophy in the University of Virginia, and there began instructing in mineralogy and geology. He remained there until 1835 , and was next appointed to the chair of natural philosophy in the University of Virginia. There he added the subjects of mineralogy and geology to his course of instruction, and organised the geological survey of the State. He remained at the head of the Geological Survey until its discontinuance in 1842 , and published annual reports, together with much valuable material which had been carefully collected. While at the University he published, for the use of the students, a short treatise on "The Strength of Materials," and a volume on "The Elements of Mechanical Philosophy." This period of his life was a very busy and attractive one, much of his time being given to original work in geology, and largely also in chemistry and physics. In the Association of American Geologists and Naturalists, organised in 1840 , Prof. Rogers took a leading part. He contributed to its volume of Transactions many valuable memoirs, among them observations on the subterranean temperature in the coal mines of Eastern Virginia. In the exploration of the physical structure of the Appalachian chain, which formed the subject of one of the memoirs above alluded to, Prof. W. B. and H. D. Rogers were associated. Their generalisations were so novel and important in the estimation of European, as well as American geologists, as to give "the Gebruder Rogers" a prominent place among their number. While a member of the Association of American Geologists he was elected several times its chairman. He presided at the meeting which expanded this last-mentioned Society into the American Association for the Advancement of Science in 1847 , and presided over the latter association at its meeting in Buffalo in 1876 .

In 1853 Prof. Rogers removed to Boston, and at once identified himself with prominent educational interests here. With a committee of gentlemen no less interested than himself in the establishment in Boston of a school which should place the teachings of science upon a more practical plane than had hitherto been attempted, he drew up a scheme entitled "Object and Plan of ân Institute of Technology," and embraced therein also a school of industrial science, a museum of arts, and a society of arts. To the accomplishment of this purpose he bent every energy, and at length a charter from the State was granted, providing the land upon whieh the institute buildings now stand. Subsequently the plans prepared by Prof. Rogers were almost completely carried out ; and he, more perhaps than any other one man, brought about that admirable system of teaching which so characterises the institute, and which finds its place in the laboratories. His connection with the institute has been a most prominent one. He occupied the chair as president for many years, and at the start was at the head of the department of physics and geology. Since his removal to Boston, as well as before, Prof. Rogers has contributed largely to scientific journals in the United States and 
Great Britain, and his articles embrace a very wide range of topics relating to the several departments of scientific research to which he had devoted himself, and many of his researches have attracted uhusual attention from their value as adding to scientific knowledge.

At the age of seventy-six his failing health compelled him to give up active duties as president, and he resigned to give place to Mr. Francis A. Walker. He still continued to hold the position of professor emeritus, and retained it at the time of his death. His health has permitted him to continue at his duties, but he has not been strong, and the cause of his death, as above stated, is supposed to have been apoplexy. He was appointed by President Hayes as President of the National Academy of Sciences, and had returned from Washington only a few days before his death, where he had been presiding over a meeting of the academy.

The New York Nation, in reference to the death of Prof. Rogers, says :-

The death of Prof. Wm. B. Rogers, in Boston, on May 30, removes not only one of the foremost of our scientific men, but perhaps the one who had in the highest degree the faculty of presenting the claims of science on popular interest and respect with force and lucidity. $\mathrm{He}$ had a remarkable gift of expression, and an unusually winning and persuasive manner, both of which were supported by a character of the utmost purity and simplicity.

\section{NOTES}

THE Council of the Society of Arts have awarded the Albert Medal of the Society of the present year to Louis Pasteur, Member of the Institute of France, For. Memb. R.S., for "his researches in connection with fermentation, the preservation of wines, and the propagation of zymotic diseases in silk worms and domestic animals, whereby the arts of wine making, silk production, and agriculture, have been greatly benefited. The Council have awarded the Society's Silver Medals to the follow. ing readers of papers during the Session 188I-2 :-To Prof. Silvanus Thompson, D.Sc., for his paper on "Storage of Electricity" ; to J. Emerson Dowson, for his paper on "The Pro. duction and Use of Gas for Purposes of Heating and Motive Power" ; to Col. G. F. Pearson, for his paper on "The Teaching of Forestry"; to Prof. Barff, M.A., for his paper on "A New Antiseptic Compound, and its Application to the Preservation of Food"; to Spencer Walpole, for his paper on "The Fish Supply of London"; to George F. Deacon, for his paper on "The Constant Supply and Waste of Water"; to Capt. Richard F. Burton, for his paper on "Gold on the Gold Coast"; to R. Warington, for his paper on "Some Practical Aspects of Recent Investigation in Nitrification"; to S. G. Thomas and Percy C. Gilchrist, for their paper on the "Manufacture of Steel from Phosphoric Pig-iron"; to Alexander M. Chance, for his paper on "The Recovery of Sulphur from Alkali Waste by Schaffner's Process, a record of recent results"; to James Mylne, for his paper on "Experiences of an European Zemindar (landholder) in Behar." Thanks were voted to the following Members of Council for the papers they had read:-To Capt. Douglas Galton, C.B., F.R.S., for his paper on "The American System of Heating Towns by Steam"; to W. H. Preece, F.R.S., for his paper on "Electric Lighting at the Paris Electrical Exhibition"; to Lieut.-Colonel C. E. Webber, R.E., for his paper on "Telephonic Communication"; to Sir Rutherford Alcock, K.C.B., for his paper on "The Opium Trade."

THE following has been forwarded to us from the Royal Society for publication :-

MY LORD,-An interesting commemoration in honour of Charles Darwin was held on Sunday last, the 2Ist instant, in the great hall of the Florence "Istituto di Studi Superiori." The commemoration was promoted by the Students in Medicine and Natural Science. The proceedings were simple, consisting of a few opening words by the Chairman of the Committee, Signor Fairman, a medical student, and a well turned and appreciative discourse by Prof. Mantegazza, whose scientific reputation is not confined to Italy. A bust of Darwin, in terra cotta, stood on the platform and marked the occasion. There were present the Prefect of Florence, the Council and Professors of the Institute, \&c., while the large hall was crowded to overflowing with a mixed and attentive audience of ladies and gentlemen, showing the interest that the occasion had evoked.

I have, \&c.,

(Signed) D. E. Colnaghi,

H.M. Consul.General.

The Right Hon. Earl Granville, K.G., \&c.

AN appreciative paper on Darwin, by the eminent naturalist, M. Alph. de Candolle, appears in the May number of Archives des Sciences. Darwin was prompt to acknowledge the work of his predecessors-Lamarck, Erasmus Darwin, and others-but seems with others to have overlooked the observations and ideas of Duchesne (r766), an evolutionist before Lamarck, to which $M$, de Candolle was able to call his attention while visiting him in 1880. Duchesne says: "The genealogical order is the only one that nature indicates, the only one that fully satisfies the mind ; every other is arbitrary and vain (vide d'idées)." In the manner of exposition of facts and in reasoning, Charles Darwin (in M. de Candolle's opinion) rather resembles Duchesne than Lamarck or Erasmus Darwin. Lamarck is more systematic. Erasmus perceives much that he does not profoundly investigate; he is diffuse and lacks scientific method. Among other things. M. de Candolle remarks that nearly all litterateurs and men of science of the first rank have lived, during part of the year at least, in a town. One can hardly cite more than two exceptions (and they are very different), viz. Voltaire and Charles Darwin. The author gives an interesting picture of his visit to Darwin, who, as a septuagenarian, he says, "etait plus animé et paraissait plus heureux que je ne l'avais vu quarante-et-un ans auparavant, Il avait l'œil vif et une expression enjouée, tandis que ses photographies montrent plutôt sa conformation de tête d'un philosophe de l'antiquité. Sa conversation variée, franche, gracieuse, - tout a fait d'un gentleman, me rappelait celle des savantes d'Oxford et de Cambridge." The author was struck with the sight of the domestic animals at Down, showing a "tranquillité qui suppose de bons maitres. . . . Vraiment, me disais-je, l'histoire des variations chez les animaux a été faite ici, et les observations doivent continuer, car Darwin n'est jamais inactif."

THE death is announced (though on doubtful authority) of Dr. Jules Crevaux, who has recently done so much for the exploration of French Guiana and the Amazon Valley. Dr. Crevaux, it is reported, has been assassinated, with his whole party, by Tobas Indians, while ascending the Pilcomayo River, on Argentine or Bolivian territory. $\mathrm{He}$ had started from Buenos Ayres, and had discovered near Salto the ruins of an ancient native city. The unfortunate explorer was only thirtyfive years of age. He was a surgeon in the French Navy, and in July, 1877 , undertook his first expedition into the interior o. Guiana. Starting from Cayenne, he traversed an almost entirely unknown region, crossed the Tumuc-Humac Mountains, the water-shed between the Maroni and the Yari, a tributary of the Amazon. On a second journey in 1878-79, Crevaux went from Cayenne to the Oyapock, followed it up, and discovered the Kow, an unknown affuent of the Yari, followed the latter to its sources, and visited and explored to their sources the littleknown affluents of the Amazon, the Paru, Iça, and Yapura. In I880 he again set out, this time to the Magdalena and the 